\title{
Preceramic Polymer Route to Amorphous and Crystalline Potassium Aluminosilicate Powders and Their Electrorheological Properties
}

\author{
Rita Baranwal ${ }^{*}$ and Richard M. Laine
}

Departments of Materials Science and Engineering and Chemistry and the Macromolecular Science and Engineering Center, University of Michigan, Ann Arbor, Michigan 48109-2136

\begin{abstract}
The oxide one-pot synthesis (OOPS) process was used to synthesize a polymer precursor to potassium aluminosilicate, $\mathrm{KAISiO}_{4}$ (KASp). A $\mathrm{KAlSiO}_{4}$ gel (KASg) also was produced via a sol-gel route using the same precursor. The two routes to $\mathrm{KAISiO}_{4}$ were explored to compare the effects of the two processing methods on powder properties. The KASp and KASg powders both transformed on heating $\left(.500^{\circ} \mathrm{C}\right)$ to amorphous, high-surface-area powders with narrow pore-size distributions (4-24 $\mathrm{nm})$. These anhydrous, amorphous powders were intrinsic electrorheological (ER) materials. Both materials crystallized at $\} 1070^{\circ} \mathrm{C}$, and thermogravimetric analysis, differential thermal analysis, and X-ray diffractometry suggested that they were identical. Diffuse reflectance infrared Fourier transform spectroscopy and scanning electron microscopy proved that the KASp powders were homogeneous, whereas the KASg powders were heterogeneous and segregated. The KASg powders exhibited better ER properties that were associated with the segregated phases.
\end{abstract}

\section{Introduction}

$\mathrm{C}$ HEMICAL (sol-gel or precursor) processing of glass and ceramic shapes can dramatically lower processing costs, compared to traditional, high-temperature powder and melt processes, because the same products can be obtained using lower processing temperatures and/or shorter times. ${ }^{1-3}$ Furthermore, chemical processing permits exceptional control over the chemical and phase purity and the microstructure of the final product. Despite these advantages, chemical processing still suffers from the high cost of the precursors, typically metal alkoxides.

Sol-gel processing suffers an additional drawback when used to process mixed-metal oxides. The wide range of hydrolysis and condensation rates of various metal alkoxides often results in chemical inhomogeneities at the gel stage. ${ }^{1}$ These inhomogeneities may be retained in the final ceramic. ${ }^{4}$ Although several groups have learned to overcome the problems inherent in sol-gel processing of mixed-metal oxides, ${ }^{4}$ this approach is still not straightforward. Furthermore, it still relies on costly metal alkoxides.

Precursor processing may offer some advantages over solgel processing, because atomic mixing relies on preformed chemical bonds in molecular species and formation of a three-

C. Randall—contributing editor

Manuscript No. 191999. Received February 26, 1996; approved December 2, 1996 Supported by the Office of Naval Research through Grant No. N00014-92-J-1711 and by the Army Research Laboratories through Contract No. DOD-C-DAAL04 91-C-0068. Author RB thanks the National Physical Science Consortium and NASALewis for a graduate fellowship.

Member, American Ceramic Society. dimensional oxide network occurs in the last processing step instead of an intermediate one. ${ }^{5}$ However, precursor processing also often relies on expensive chemical compounds and can suffer from carbon retention in the pyrolyzed products. To overcome these problems, we have developed a synthetic route to mixed-metal alkoxide precursors directly from the oxides themselves.

We previously reported the synthesis of silicate precursors by reacting silica $\left(\mathrm{SiO}_{2}\right)$ with Group I $(\mathrm{M}=\mathrm{Li}, \mathrm{Na}, \mathrm{K}, \mathrm{Cs})$ metal hydroxides or Group II $(\mathrm{M}=\mathrm{Mg}, \mathrm{Ca}, \mathrm{Sr}, \mathrm{Ba})$ metal oxides in excess ethylene glycol (EG, see below). ${ }^{3,5}$ This approach was then extended to a one-step synthesis of aluminosilicate alkoxide precursors from $\mathrm{SiO}_{2}$ and aluminum hydroxide $\left(\mathrm{Al}(\mathrm{OH})_{3}\right)$. This approach, called the oxide one-pot synthesis, or OOPS, process, offers considerable potential for processing numerous aluminosilicate materials. ${ }^{6}$

OOPS provides processable precursors, atomic mixing of reaction components, and control over product stoichiometry, and the process uses inexpensive starting materials. OOPS permits low-temperature syntheses of alkali and alkaline silicate, aluminate, and aluminosilicate precursors of any stoichiometry including spinel $\left(\mathrm{MgAl}_{2} \mathrm{O}_{4}\right)$, mullite, cordierite, celsian, $\beta^{\prime \prime}$-alumina $\left(\beta^{\prime \prime}-\mathrm{Al}_{2} \mathrm{O}_{3}\right)$, and strontium and barium aluminosilicates. ${ }^{5-9}$ These precursors provide access to protective ceramic coatings, fibers, and high-surface-area lithium and sodium aluminosilicate powders for electrorheological (ER) applications. ${ }^{5,9}$

The work that is presented here explores the utility of an OOPS potassium aluminosilicate $\left(\mathrm{KAlSiO}_{4}, \mathrm{KAS}\right)$ composition precursor for processing $\mathrm{KAlSiO}_{4}$ (kaliophilite) powders using precursor and sol-gel processing methods. The precursor-toceramic transformation process is mapped using a number of analytical methods, and the ER behavior of the resulting powders is examined.

\section{Background}

\section{(1) Oxide One-Pot Synthesis (OOPS) Process}

The first step in development of the OOPS process was the discovery that Group I silicate precursors can be synthesized via reactions (1) and (2): ${ }^{10}$

$$
\mathrm{SiO}_{2}+\mathrm{MOH}+3 \mathrm{HO} \frown \mathrm{OH} \frac{-3 \mathrm{H}_{2} \mathrm{O}}{\sim 200^{\circ} \mathrm{C}} \mathrm{M}\left[\mathrm{O}_{\mathrm{O}}^{\mathrm{O}}\right]_{2} \mathrm{Si}^{-} \mathrm{O}_{\mathrm{O}^{\prime}}
$$

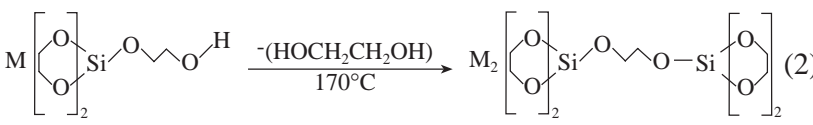

for $\mathrm{M}=\mathrm{Li}, \mathrm{Na}, \mathrm{K}$, and Cs. Pyrolysis of the dimer, reaction (2), typically provides phase-pure silicates, $\mathrm{M}_{2} \mathrm{O} \cdot 2 \mathrm{SiO}_{2} \cdot{ }^{3}$ Reaction of $\mathrm{SiO}_{2}$ with Group II (Mg, $\mathrm{Ca}, \mathrm{Ba}, \mathrm{Sr}$ ) oxides, in excess EG, provides hexacoordinate, dianionic tris(glycolato)silicate com- 
plexes (reaction (3)), which transform when heated to the Group II silicates. ${ }^{5}$

$$
\left.\mathrm{SiO}_{2}+\mathrm{MO}+\mathrm{HO} \mathrm{OH} \stackrel{-3 \mathrm{H}_{2} \mathrm{O}}{\longrightarrow} \mathrm{MSi}_{[\mathrm{O}}^{[\mathrm{O}}\right]_{3}
$$

for $\mathrm{M}=\mathrm{Mg}, \mathrm{Ca}, \mathrm{Ba}$, and $\mathrm{Sr}$.

Most recently, in work that has been reported elsewhere, ${ }^{11}$ we discovered that amine bases provide access to new precursors. Thus, $\mathrm{SiO}_{2}$ reacts with triethanolamine (TEA, reaction (4)) to produce silatrane glycolate, $\mathrm{TEASiOCH}_{2} \mathrm{CH}_{2} \mathrm{OH}$.

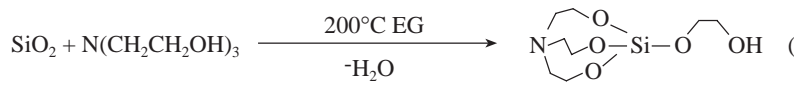

Quantitative yields, at the $100 \mathrm{~g}$ scale, can be obtained in 4-5 h. Similarly, aluminum (alumatrane) analogs form (reaction (5)) in the same times and scales: ${ }^{6,11}$

$$
\mathrm{Al}(\mathrm{OH})_{3}+\mathrm{N}\left(\mathrm{CH}_{2} \mathrm{CH}_{2} \mathrm{OH}\right)_{3} \stackrel{20{ }^{\circ} \mathrm{C} \mathrm{EG}}{-{ }_{-} \mathrm{O}}[\underbrace{\mathrm{N}^{\mathrm{O}} \mathrm{O}^{\prime}-\mathrm{Al}}_{\mathrm{O}^{\prime}}]_{4}
$$

Combining reactions (2)-(5) provides the basis for OOPS precursors.

Precursors of any stoichiometry can be synthesized simply by mixing the appropriate reactants, as illustrated in the generic reaction

$$
\begin{array}{r}
x \mathrm{MOH}+y \mathrm{SiO}_{2}+z \mathrm{Al}(\mathrm{OH})_{3}+(x+y+z) \mathrm{TEA}_{2}^{200^{\circ} \mathrm{C} / \text { excess } \mathrm{EG} / 4-8 \mathrm{~h} /-\mathrm{H}_{2} \mathrm{O}} \longrightarrow \\
\mathrm{M}_{x} \mathrm{Si}_{y} \mathrm{Al}_{z}(\mathrm{TEA})_{x+y+z}
\end{array}
$$

All the aluminosilicate precursors produced via reaction (6) are processable, soluble, polymer-like solids. ${ }^{8-11}$ In general, when pyrolyzed in air or $\mathrm{O}_{2}$ to temperatures of $\sim 700^{\circ} \mathrm{C}$, these precursors transform to the corresponding amorphous materials with no apparent change in initial stoichiometry. ${ }^{3}$ In most instances, additional heating to higher temperatures results in crystallization. ${ }^{9}$ The molecular structures for these precursors remain to be fully defined; however, preliminary mass-spectral analyses and nuclear magnetic resonance (NMR) studies suggest structures similar to the following for Group I metals: ${ }^{12}$

$$
\overbrace{\mathrm{O}^{-}}^{\mathrm{O}} \mathrm{Hl}_{\mathrm{H}^{\prime}} \mathrm{O}^{-}
$$

The long-term objectives of the present studies are threefold. The first objective is to synthesize and characterize inexpensive, processable aluminosilicate precursors using the OOPS process. The second is to establish appropriate processing conditions for converting the precursor to the corresponding amorphous aluminosilicate and then to the crystalline material, if desired. The third objective is to demonstrate applications for the OOPS-derived materials. In the current work, we compare and contrast the properties of KAS powders, especially with respect to their ER behavior, that have been prepared using two processing routes. In one route, KAS bulk powder (KASp) is synthesized by direct air pyrolysis of the precursor. In the second, powder (KASg) is synthesized via sol-gel processing with $5 \mathrm{wt} \%$ precursor dissolved in $95 \mathrm{wt} \%$ of deionized water.

\section{(2) Electrorheological Fluids}

Suspensions of aluminosilicate powders in nonconducting fluids behave as ER systems. ${ }^{13}$ These systems respond rapidly and reversibly to the application of high voltage, sometimes resulting in an increase in fluid viscosity of two-to-three orders of magnitude..$^{13}$ ER systems offer potential as damping devices, for noise and vibration control, and, in the automotive and aerospace industries, as semiactive dynamic control systems. ${ }^{14,15}$ Because water increases the effective permittivity of the dispersed phase, ${ }^{15}$ its presence can induce ER effects, often evident because of differences in permittivity. ${ }^{14}$ "Water-activated" fluids ( $>5 \mathrm{vol} \% \mathrm{H}_{2} \mathrm{O}$; up to $5 \mathrm{vol} \% \mathrm{H}_{2} \mathrm{O}$ is sometimes designated as substantially anhydrous), because of the volatility of water, are effective only in a limited temperature range, are unstable, and exhibit irreproducible properties. Thus, there is a strong desire to find fully anhydrous ER fluids.

Those materials whose ER behavior results from their surface chemistry (i.e., hydroxyl $(\mathrm{OH})$ groups and mobile ions on the surface), rather than being a result of added dispersants/ surfactants (i.e., $\mathrm{H}_{2} \mathrm{O}$ or other polar compounds), are considered intrinsic ER materials. $\mathrm{SiO}_{2}{ }^{16-18}$ and metal oxides ${ }^{19-21}$ are candidates for the dispersed phase in water-activated ER fluids. The OOPS-derived aluminosilicate precursors and gels that are described here can be converted to high-specific-surface-area (high-SSA) materials; thus, they are potentially useful as intrinsic ER materials. Aluminosilicates with high SSAs are known to exhibit good-to-excellent ER behavior. ${ }^{13,22,23}$

The ER behavior of lithium aluminosilicate (LAS) and sodium aluminosilicate (NAS) precursor-derived powders was examined previously, ${ }^{9,24}$ and a detailed method of preparing LAS/NAS powders and ER fluids was developed. The processing protocols and powder properties of OOPS-derived KAS are reported here, for comparison with the LAS/NAS studies and as a continuation of our model studies on OOPS-derived aluminosilicates.

\section{Experimental Procedure}

All materials were handled using standard Schlenk techniques. All chemicals were purchased from standard vendors and used as received. Potassium hydroxide $(87 \% \mathrm{KOH})$ and analytical, reagent-grade ethylene glycol (EG) were obtained from Mallinckrodt, Paris, KY. The EG that was recovered from the reactions was distilled under nitrogen gas $\left(\mathrm{N}_{2}\right)$ and recycled. Silica $\left(99 \% \mathrm{SiO}_{2}\right)$ was obtained from Cabot Corp., Tuscola, $\mathrm{IL}$. Aluminum hydroxide hydrate $\left(\mathrm{Al}(\mathrm{OH})_{3} \cdot x \mathrm{H}_{2} \mathrm{O}, 57 \% \mathrm{Al}_{2} \mathrm{O}_{3}\right)$ and TEA were obtained from Aldrich Chemical Co., Milwaukee, WI.

\section{(1) KAS Synthesis}

In a standard OOPS synthesis, ${ }^{6} 1.0$ equiv of metal hydroxide $(\mathrm{MOH})$ is reacted with 1.0 equiv of $\mathrm{SiO}_{2}, 1.0$ equiv of $\mathrm{Al}(\mathrm{OH})_{3}$. $x \mathrm{H}_{2} \mathrm{O}$, and 1.0 equiv of TEA per metal ion in excess EG. The reaction proceeds at $\sim 200^{\circ} \mathrm{C}$ with continuous distillative removal of water that is formed as a byproduct of $\mathrm{SiO}_{2}$, $\mathrm{Al}(\mathrm{OH})_{3}$, and $\mathrm{MOH}$ dissolution. The reaction is complete when it turns clear (typically 3-5 h). The sample is then cooled to room temperature (RT).

(A) $\mathrm{KAlSiO}_{4}$ Precursor $(K A S p): \mathrm{KOH}(0.32 \mathrm{~mol}), \mathrm{SiO}_{2}$ $(0.32 \mathrm{~mol}), \mathrm{Al}(\mathrm{OH})_{3} \cdot x \mathrm{H}_{2} \mathrm{O}(0.32 \mathrm{~mol})$, TEA $(0.99 \mathrm{~mol})$, and EG $(500 \mathrm{~mL})$ were placed in a three-necked flask (capacity of $1 \mathrm{~L})$ equipped with a still head. The mixture was mechanically stirred and heated at $\sim 200^{\circ} \mathrm{C}$ under flowing $\mathrm{N}_{2}$ to promote reaction. EG and byproduct $\mathrm{H}_{2} \mathrm{O}$ were distilled off. After $3 \mathrm{~h}$, following distillative removal of $200 \mathrm{~mL}$ of $\mathrm{EG}$, the solution became viscous and cloudy. After $5 \mathrm{~h}$, the reaction became clear, indicating complete dissolution of the oxides. The remaining EG was distilled off to concentrate the solution to $\sim 200 \mathrm{~mL}$. The resulting solid was dried (4 h under a dynamic vacuum of $\sim 1.33 \mathrm{~Pa}\left(10^{-2}\right.$ torr $)$ at $\left.200^{\circ} \mathrm{C}\right)$ to remove any remaining EG and unreacted TEA. This transparent brittle solid was cooled to liquid- $\mathrm{N}_{2}$ temperature and ground with an alumina $\left(\mathrm{Al}_{2} \mathrm{O}_{3}\right)$ mortar and pestle to give $190 \mathrm{~g}$ of precursor powder.

(B) $\mathrm{KAlSiO}_{4} \mathrm{Gel}(\mathrm{KASg}): \mathrm{A} 5 \mathrm{wt} \% \mathrm{KAlSiO}_{4}$ gel was prepared at room temperature, in air, by dissolving $44 \mathrm{~g}$ of the above KASp precursor in a magnetically stirred beaker (capacity of $1 \mathrm{~L}$ ) containing $190 \mathrm{~mL}$ of deionized $\mathrm{H}_{2} \mathrm{O}$. The bulk 
precursor dissolved in 2-3 min and gelled within 5 min. Water from the sample was allowed to evaporate at RT, in air, for $24 \mathrm{~h}$.

\section{(2) Precursor and Gel Pyrolyses}

The bulk precursor and gel samples were first characterized by thermogravimetric analysis (TGA) to define a processing window for the pyrolytic transformation of both to glass and ceramic materials. These TGA profiles provided information on the decomposition patterns of KASp and KASg materials and were used to establish isothermal pyrolysis schedules for converting the precursor and the gel to low-temperature glasses.

A two-step heat treatment at $400^{\circ} \mathrm{C}$ was used to convert KASp and KASg samples to amorphous, porous, compositionally correct $\mathrm{KAlSiO}_{4}$ (potassium aluminum orthosilicate, kaliophilite) powders. In the first staged heating step (Table I), samples were heated $\left(400^{\circ} \mathrm{C}\right.$ in air) to oxidatively remove most of the organics. The resulting products contained $\sim 5 \mathrm{wt} \%$ carbon and were pyrolyzed again at $400^{\circ} \mathrm{C}$ in oxygen gas $\left(\mathrm{O}_{2}\right)$. Samples $(10 \mathrm{~g})$ were heated $\left(8 \mathrm{~h}\right.$ under flowing $\mathrm{O}_{2}$ at a flow rate of $8 \mathrm{~mL} / \mathrm{s}$ ) in $\mathrm{Al}_{2} \mathrm{O}_{3}$ crucibles in a single-zone furnace.

A third and final heat treatment step used individual samples of the $400^{\circ} \mathrm{C}$ oxidized KASp and KASg powders. All samples were further heated $\left(500^{\circ} \mathrm{C}\right.$ for $8 \mathrm{~h}$ under flowing dry air at a flow rate of $8 \mathrm{~mL} / \mathrm{s}$ ) to remove traces of remaining carbon. Samples were then heated under flowing dry air $(8 \mathrm{~mL} / \mathrm{s})$ at a heating rate of $10^{\circ} \mathrm{C} / \mathrm{min}$ to temperatures of $500^{\circ}-1400^{\circ} \mathrm{C}$.

\section{(3) Characterization Methods}

The resulting KASp and KASg powders were characterized using TGA, differential thermal analysis (DTA), X-ray diffractometry (XRD), diffuse reflectance infrared Fourier transform spectroscopy (DRIFTS), porosimetry, and scanning electron microscopy (SEM). Powder suspensions also were tested for ER activity.

(A) TGA: Thermal analyses of the bulk and gel aluminosilicates were performed using a thermal analyzer (Model 2200, TA Instruments, New Castle, DE) that was equipped with a thermogravimetric analyzer module (Model Hi-Res TGA 2950, TA Instruments). TGA samples $(10-15 \mathrm{mg}$ ) were loaded on a platinum pan and heated at a rate of $50^{\circ} \mathrm{C} / \mathrm{min}$ to $1000^{\circ} \mathrm{C}$, in Hi-Res ${ }^{\text {TM }} 4.0$ mode. The Hi-Res ${ }^{\text {TM }}$ ramp-rate program decreases the heating rate when the rate of mass loss increases, thus providing sharply defined thermal events. The TGA balance was flushed with $\mathrm{N}_{2}(40 \mathrm{~mL} / \mathrm{min})$ while the TGA furnace was purged with synthetic air $(60 \mathrm{~mL} / \mathrm{min})$.

(B) DTA: DTA of the aluminosilicate precursors and converted ceramics was performed using a similar thermal analyzer (Model 2200, TA Instruments) in conjunction with a differential scanning calorimeter module (Model 2910, TA Instruments) that was equipped with a differential thermal analyzer (Model 1600, TA Instruments). The DTA was calibrated with gold. The measurements $(\sim 20 \mathrm{mg}$ samples) were performed using platinum crucibles, under a continuous flow of synthetic air $\left(40 \mathrm{~mL} / \mathrm{min}\right.$ ), at a heating rate of $10^{\circ} \mathrm{C} / \mathrm{min}$ to $1400^{\circ} \mathrm{C}$. Calcined $\mathrm{Al}_{2} \mathrm{O}_{3}$ (ALCOA, Pittsburgh, PA) was used as a reference.

(C) XRD: Samples were analyzed by powder XRD using a rotating anode goniometer (Rigaku Denki Co., Ltd., Tokyo, Japan). Powder samples (100-200 mg) were ground with an

Table I. Staged Heating for First Pyrolysis Step

\begin{tabular}{ccc}
\hline $\begin{array}{c}\text { Ramp rate } \\
\left({ }^{\circ} \mathrm{C} / \mathrm{h}\right)\end{array}$ & $\begin{array}{c}\text { Temperature } \\
\left({ }^{\circ} \mathrm{C}\right)\end{array}$ & $\begin{array}{c}\text { Dwell time } \\
(\mathrm{h})\end{array}$ \\
\hline 60 & 70 & 4.0 \\
60 & 85 & 3.0 \\
60 & 95 & 2.0 \\
60 & 100 & 3.0 \\
60 & 110 & 2.0 \\
60 & 200 & 2.0 \\
60 & 275 & 2.0 \\
60 & 300 & 2.0 \\
60 & 400 & 4.0 \\
\hline
\end{tabular}

$\mathrm{Al}_{2} \mathrm{O}_{3}$ mortar and pestle, packing into a glass specimen holder, and then placed into the goniometer. Scans were measured over the range of $5^{\circ}-80^{\circ} 2 \theta$ at a scan rate of $2^{\circ} 2 \theta /$ min using $0.05^{\circ} 2 \theta$ increments and $\mathrm{CuK \alpha}(\lambda=0.1542 \mathrm{~nm}(1.542 \mathrm{~A}))$ radiation operating at $40 \mathrm{kV}$ and $100 \mathrm{~A}$.

(D) DRIFTS: DRIFTS spectra were recorded on a Galaxy Series FTIR 3000 spectrometer (Mattson Instruments, Madison, WI). Random cuttings of optical-grade, single-crystal potassium bromide $(\mathrm{KBr})$ (International Crystal Laboratories, Garfield, $\mathrm{NJ}$ ) were ground using an $\mathrm{Al}_{2} \mathrm{O}_{3}$ mortar and pestle. The ground $\mathrm{KBr}$ powder was used as the nonabsorbing medium. DRIFTS samples were prepared in air by rigorously mixing $0.5 \mathrm{wt} \%$ of analyte with ground $\mathrm{KBr}$, followed by the addition of $10 \mathrm{mg}$ of ground sample to $200 \mathrm{mg}$ of ground $\mathrm{KBr}$; this mixture was ground together, and $50 \mathrm{mg}$ of it was then ground together with $400 \mathrm{mg}$ of ground $\mathrm{KBr}$ to create a $0.5 \mathrm{wt} \%$ sample in $\mathrm{KBr}$. Sample concentrations were maintained at $<1 \mathrm{wt} \%$ to ensure adherence to Beer's law. The dilute samples were then packed into sample holders, leveled off at the upper edge to provide a smooth surface, and transferred to the sample chamber, which was constantly flushed with $\mathrm{N}_{2}$. A minimum of 1000 scans was collected for each sample at a resolution of $\pm 4 \mathrm{~cm}^{-1}$. Diffuse reflectance peak positions were identified using a standard peak-searching program.

(E) Surface Area and Porosimetry: Specific surface areas (SSAs) and micropore analyses were conducted at $77 \mathrm{~K}$ using a sorption analyzer (Model ASAP 2000, Micromeritics Instrument Corp., Norcross, GA), with $\mathrm{N}_{2}$ as the adsorbate gas. Prior to analysis, samples were degassed at $110^{\circ} \mathrm{C}$ for $4 \mathrm{~h}$, then at $400^{\circ} \mathrm{C}$ until the degas rate was below $\sim 1.3 \mathrm{~Pa} / \mathrm{min}\left(10^{-2}\right.$ torr/min). SSAs were calculated using the Brunauer-EmmettTeller (BET) multipoint method. Micropore analyses were conducted using the density functional theory (DFT) and a model that uses a set of isotherms in which $\mathrm{N}_{2}$ is adsorbed on a carbon substrate with slitlike pores. Thus, pore sizes were reported as pore widths. ${ }^{8,25}$ Analysis was performed with a software package that was supplied with the instrument.

(F) SEM: Powder morphologies were examined using an SEM microscope (Model S 800, Hitachi, Tokyo, Japan) that was operated at $5 \mathrm{eV}$. The samples were prepared for SEM by mounting the pyrolyzed powder samples on an aluminum stub with double-sided tape. The samples were then sputter coated with two layers $\left(45^{\circ}\right.$ and $-45^{\circ}$ off-axis) of gold/palladium for $90 \mathrm{~s}$ at $10 \mathrm{mV}$, to reduce particle charging.

$(G)$ ER Behavior: Samples were ground and sieved $(-200$ mesh; $75 \mu \mathrm{m})$ with an $\mathrm{Al}_{2} \mathrm{O}_{3}$ mortar and pestle. The samples were then sealed in a tube furnace (Type 21100, Model F21125, Themolyne, Dubuque, IA) under dynamic vacuum and heated to remove physisorbed water. Samples $(3 \mathrm{~g})$ were dried at $150^{\circ} \mathrm{C}$ for $4 \mathrm{~h}$ and then cooled to RT under vacuum. Mineral oil (Mallinckrodt) was added to the sample under vacuum in a ratio of $8 \mathrm{~mL}$ per $3 \mathrm{~g}$ of sample.

ER behavior was tested using the following procedure: samples in mineral oil (still under vacuum) were opened to air and transferred immediately to a couette cell (Fig. 1) in a rheogoniometer (Model R16, Weissenberg, U.K.) connected to a high-voltage dc supply (Model R10B, Hipotronics, Brewster, NY). Measurements were taken at RT using a constant shear rate of $0.02 \mathrm{~s}^{-1}$. An electric field was applied slowly to the couette cell, and torque was measured on the upper bob. Torque deflections were recorded every $0.5 \mathrm{kV} / \mathrm{mm}$ until the sample underwent dielectric breakdown. ${ }^{21}$ The ER activity was measured as shear stress (in units of pascals $(\mathrm{Pa})$ ).

\section{Results and Discussion}

\section{(1) TGA/Selecting Processing Conditions}

TGA of the KASp and KASg precursors (Fig. 2) gives $1000^{\circ} \mathrm{C}$ ceramic yields of $23 \%$ and $5.9 \%$, respectively. These values are close to the theoretical values $(26 \%$ and $5 \%$, respectively) that have been calculated for the initial HKAlSi$\left[\left(\mathrm{OCH}_{2} \mathrm{CH}_{2}\right)_{3} \mathrm{~N}\right]_{3}$ composition. ${ }^{12}$ The lower KASp yields are 


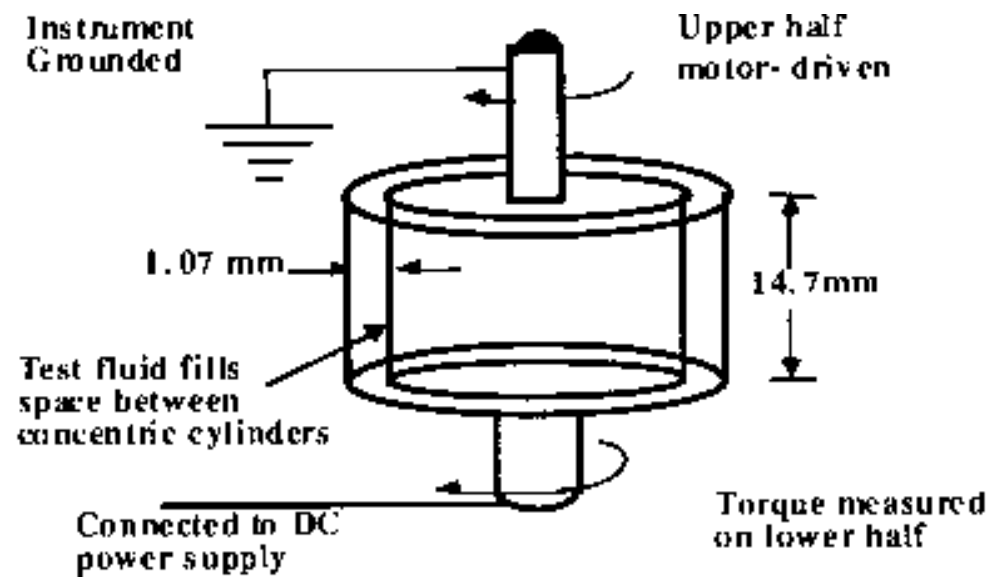

Fig. 1. Cup/couette cell of Weissenberg rheogoniometer used to measure ER activity.

due to trace amounts of entrapped EG or TEA, which are difficult to remove, even by vacuum evaporation. The higher KASg ceramic yield might result as a consequence of the syneresis that occurs as the gel ages.

The TGA profiles were used to delineate bulk sample pyrolysis conditions, to ensure ligand decomposition and carbon removal without promoting diffusion/uncontrolled crystallization. The TGA profiles indicate that the major portion of organics $(65 \mathrm{wt} \%) / \mathrm{gel}$ water $(90 \mathrm{wt} \%)$ was eliminated when KASp/ $\mathrm{KASg}$ precursor samples were heated to $400^{\circ} \mathrm{C}$. Based on the above-mentioned requirements and to be consistent with previous studies, ${ }^{3,9,24}$ a three-step heat treatment schedule was developed to permit direct comparison of the two materials as they evolve. The solids were first heated in stages to allow the slow escape of volatiles to minimize the probability of combustion.

The first staged pyrolysis step $\left(400^{\circ} \mathrm{C}\right.$ in air; see Table I) converts the KASp and KASg samples both to black powders containing $\sim 5 \mathrm{wt} \%$ of carbon by TGA. A second, fixed-bed oxidation step removes this residual carbon $\left(400^{\circ} \mathrm{C}\right.$ for $8 \mathrm{~h}$ under flowing $\mathrm{O}_{2}$ at a flow rate of $8 \mathrm{~mL} / \mathrm{s}$ ). A third heat treatment $\left(500^{\circ} \mathrm{C}\right.$ for $8 \mathrm{~h}$ in air at a flow rate of $\left.8 \mathrm{~mL} / \mathrm{s}\right)$ is required to remove remaining traces of carbon, resulting in amorphous, carbon-free powders.

The $500^{\circ} \mathrm{C} \mathrm{KASg}$ and KASp materials are high-surface-area powders (see below) and should readily adsorb $\mathrm{H}_{2} \mathrm{O}$ and $\mathrm{CO}_{2}$ from the atmosphere. Indeed, the DRIFTS studies below suggest the presence of adsorbed $\mathrm{H}_{2} \mathrm{O}$ (bridging $\mathrm{OH}$ species). Thus, a second TGA study was conducted to establish the source of these bridging OHs. In this study, samples of bulk pyrolyzed material were loaded in the TGA, heated $\left(50^{\circ} \mathrm{C} / \mathrm{min}\right)$ to their final pyrolysis temperatures, and held for $20 \mathrm{~min}$. Samples were cooled to RT (in the TGA furnace) and held for $40 \mathrm{~min}$. TGA profiles were then rerun as usual without exposure to ambient atmosphere. Ceramic yields for the KASp samples ranged from $93.7 \mathrm{wt} \%$ (KASp at $400^{\circ} \mathrm{C}$ ) to $99.3 \mathrm{wt} \%$ (KASp at $900^{\circ} \mathrm{C}$ ), and ceramic yields for the KASg samples ranged from $95.0 \mathrm{wt} \%$ $\left(\mathrm{KASg}\right.$ at $\left.400^{\circ} \mathrm{C}\right)$ to $99.3 \mathrm{wt} \% \mathrm{KASg}$ at $\left.900^{\circ} \mathrm{C}\right)$. In each instance, mass losses were observed in the $75^{\circ}-175^{\circ} \mathrm{C}$ range (attributed to $\mathrm{H}_{2} \mathrm{O}$ loss from surface $\mathrm{OHs}$ ) and again in the $800^{\circ}-950^{\circ} \mathrm{C}$ range (attributed to $\mathrm{CO}_{2}$ evolution; see discussion below). For the $400^{\circ}$ (not subjected to the third bulk-oxidation step) and $500^{\circ} \mathrm{C}$ samples, the additional $1 \%-2 \%$ mass loss observed in the $550^{\circ}-700^{\circ} \mathrm{C}$ range can be attributed to the oxidation of free carbon. Because the samples were never exposed to an ambient atmosphere, these surface $\mathrm{OHs}$ must originate from ligand decomposition/oxidation during pyrolysis. The TGA profiles indicate that the mass-loss behavior of the KASp and KASg samples is very similar, implying that KASp and KASg both exhibit similar surface diffusion behavior and surface chemistries. However, the DRIFTS data contradicts this implication.

The TGA profiles all exhibit well-resolved mass losses in the $800^{\circ}-950^{\circ} \mathrm{C}$ range, which are also observed for potassium glycolatosilicate. ${ }^{3}$ In the latter case, these losses are associated with $\mathrm{CO}_{2}$ evolution that occurs concurrent with the reaction of the potassium species with $\mathrm{SiO}_{2}$. Assuming that the mass loss is due entirely to $\mathrm{CO}_{2}$ evolution, we can back calculate the mass of potassium carbonate $\left(\mathrm{K}_{2} \mathrm{CO}_{3}\right)$ present at $\sim 800^{\circ} \mathrm{C}$. The amount of $\mathrm{CO}_{2}$ that evolved in the KASp samples after $800^{\circ} \mathrm{C}$ ranged from $1.0 \mathrm{wt} \%\left(\mathrm{KASp}\right.$ at $400^{\circ} \mathrm{C}$ ) to $0.0 \mathrm{wt} \%$ (KASp at $900^{\circ} \mathrm{C}$ ). The amount of $\mathrm{CO}_{2}$ that evolved in the KASg samples after $800^{\circ} \mathrm{C}$ ranged from $0.8 \mathrm{wt} \%$ (KASg at $400^{\circ} \mathrm{C}$ ) to $0.0 \mathrm{wt} \%$ (KASg at $900^{\circ} \mathrm{C}$ ). From this information, the amount of $\mathrm{K}_{2} \mathrm{CO}_{3}$ that was present at $\sim 800^{\circ} \mathrm{C}$ can be calculated. The amount of $\mathrm{K}_{2} \mathrm{CO}_{3}$ that was present at $\sim 800^{\circ} \mathrm{C}$ in the KASp samples ranged from $3.1 \mathrm{wt} \%\left(\mathrm{KASp}\right.$ at $400^{\circ} \mathrm{C}$ ) to $0.0 \mathrm{wt} \%$ (KASp at $900^{\circ} \mathrm{C}$ ). The amount of $\mathrm{K}_{2} \mathrm{CO}_{3}$ that was present at $\sim 800^{\circ} \mathrm{C}$ in the $\mathrm{KASg}$ samples ranged from $2.5 \mathrm{wt} \%$ (KASg at $400^{\circ} \mathrm{C}$ ) to $0.0 \mathrm{wt} \%$ (KASg at $900^{\circ} \mathrm{C}$ ). The mass losses for both KASp and KASg are very similar, implying very similar materials, even at the atomic level.

The KASp TGA profile (Fig. 2, top) shows that most of the mass loss $(60 \mathrm{wt} \%)$ occurs before attaining a temperature of $400^{\circ} \mathrm{C}$. In contrast, the KASg TGA profile (Fig. 2, bottom) shows that the most mass is lost before attaining a temperature of $\sim 225^{\circ} \mathrm{C}$. The difference results because the KASg sample loses trapped water, whereas the KASp samples must lose alkoxide ligands. These differences have a profound effect on DTA analyses.

\section{(2) DTA}

DTA studies were conducted for three purposes. These purposes were (i) to examine the thermodynamics of selected TGA mass-loss events, (ii) to correlate crystallization events with the appearance of powder patterns in the XRD studies, and (iii) to determine the onset temperature of crystallization more accurately.

DTAs of KASp samples (Fig. 3, top) show small exotherms at $400^{\circ}$ and $430^{\circ} \mathrm{C}$ and a larger exotherm at $575^{\circ} \mathrm{C}$. In contrast, DTAs of KASg samples (Fig. 3, bottom) show small exotherms at $340^{\circ}, 390^{\circ}$, and $435^{\circ} \mathrm{C}$. Nass et al. ${ }^{26}$ reported that, in sol-gelderived mullite samples, an exotherm is observed at $330^{\circ} \mathrm{C}$ that is associated with the oxidation of residual alkoxy ligands; this assignment was supported by coupled TGA-mass-spectral results that show the coincident evolution of $\mathrm{CO}_{2}$ and $\mathrm{H}_{2} \mathrm{O}$. A similar explanation is reasonable for the $\mathrm{KASg} 340^{\circ} \mathrm{C}$ exotherm observed here. The difference in temperatures can be ascribed to differences in heating rates and the fact that the alkoxy groups are different.

The presence of exotherms in sol-gel materials in this same region $\left(\sim 400^{\circ} \mathrm{C}\right)$ also has been suggested to occur because of pore collapse. ${ }^{1}$ Still another possible source of exotherms might be the formation of an aluminosilicate skeletal framework. We consider each possibility, beginning with a proposed explanation for the absence of a $340^{\circ} \mathrm{C}$ exotherm in the KASp samples. 


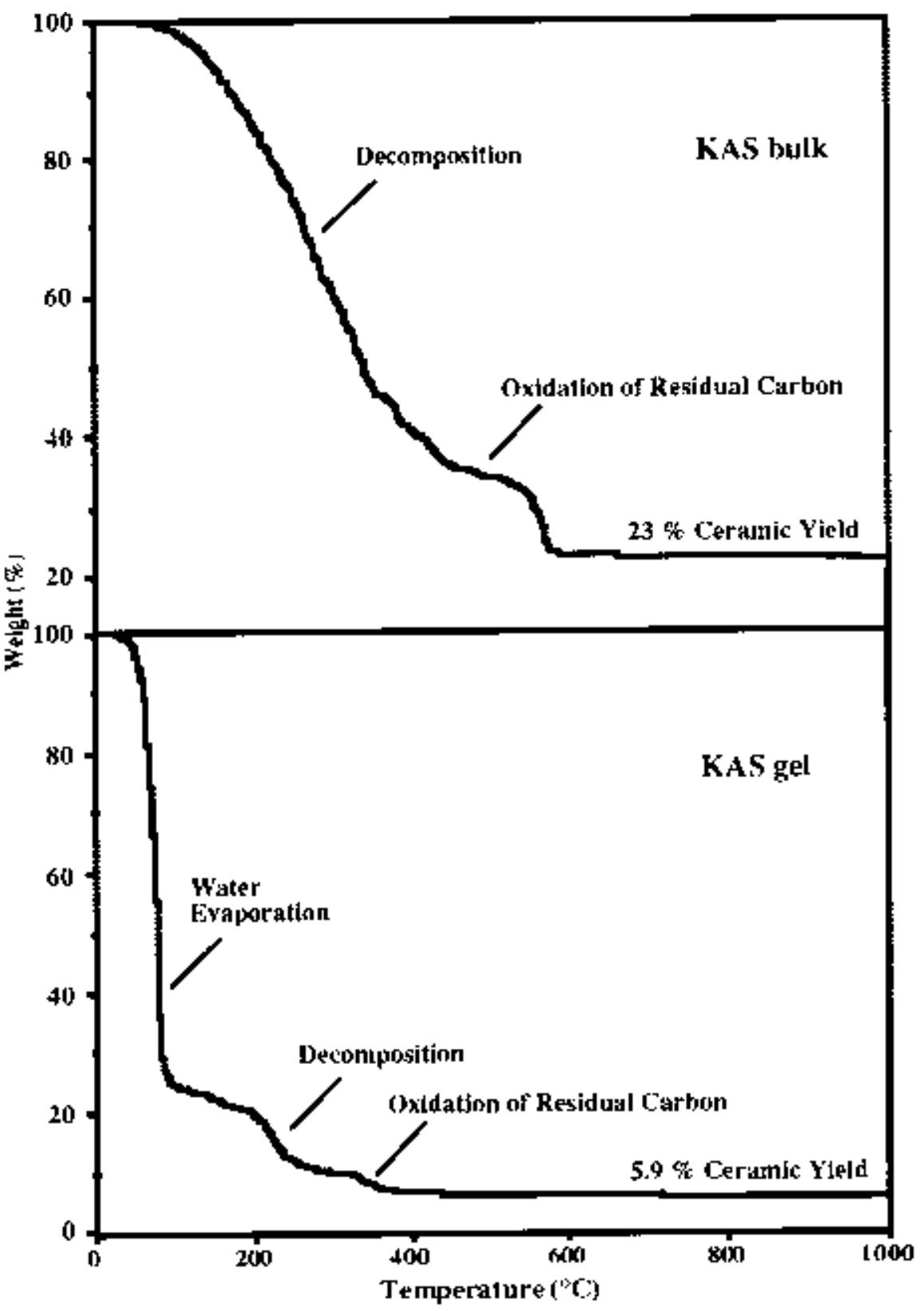

Fig. 2. TGA profiles for KAS bulk (KASp) and KAS gel (KASg) precursors. Ramp was $10^{\circ} \mathrm{C} / \mathrm{min}$ in synthetic air.

Exothermic oxidation of residual ligands requires that $\mathrm{O}_{2}$ find these remaining ligands, which is easy in dried gels because they offer considerable open porosity (see below) and, therefore, access to residual ligands. In contrast, the KASp samples lose the major portion of their mass and gases evolve at relatively high rates in the $200^{\circ}-400^{\circ} \mathrm{C}$ temperature range. During this period, there is considerable egress of gas, most likely coincident with the formation of open porosity. The ingress of $\mathrm{O}_{2}$ must occur but at rates limited by the gases that are evolving, leading to processes that occur in $\mathrm{O}_{2}$-deficient environments, i.e., oxidative crosslinking (see below), rather than combustion. However, once the volatile ligand mass is lost, open porosity exists and residual ligands may then be oxidized. Thus, it can be argued that the oxidation of residual ligands in KASp samples might occur at higher temperatures, accounting for either the $400^{\circ}$ or $430^{\circ} \mathrm{C}$ exotherm. However, the $400^{\circ}$ and $430^{\circ} \mathrm{C}$ exotherms both are observed for all the aluminosilicate precursors that we have studied to date, regardless of the pyrolysis atmosphere. ${ }^{5}$ Thus, the oxidation of residual ligands is an unlikely explanation for the exotherms that have been observed for KASp. Two other possible explanations remain.
The sol-gel process is known to create microporosity. ${ }^{1}$ Thus, the KASg samples can be expected to be partially microporous, as demonstrated below. Given that the KASp thermolysis process also creates microporosity, the collapse of the very smallest, highest-surface-curvature pores is likely to release some free energy; this could account for one of the small exotherms that is observed for both materials at $390^{\circ}-435^{\circ} \mathrm{C}$.

The very high mass loss that is associated with KASp decomposition at temperatures that are just $<400^{\circ} \mathrm{C}$ leads to formation of microporosity, which implies the formation of an aluminosilicate framework. Unlike the KASg samples, this framework does not exist before ligand decomposition occurs. The pyrolysis process, most likely, first generates isolated $\left(\mathrm{Si}(\mathrm{OH})_{x}\right.$ and $\mathrm{Al}(\mathrm{OH})_{y}$ species that then condense to form an amorphous aluminosilicate network. The local ordering of this network that occurs during condensation could account for one of the KASp exotherms. A similar, but smaller, exotherm also may result from the final formation of an aluminosilicate framework in the KASg samples, as the final $\mathrm{OH}$ groups condense (see DRIFTS section, Section IV(4)). On this basis, it seems that the $400^{\circ} \mathrm{C}$ exotherms correspond to network formation in both samples. 


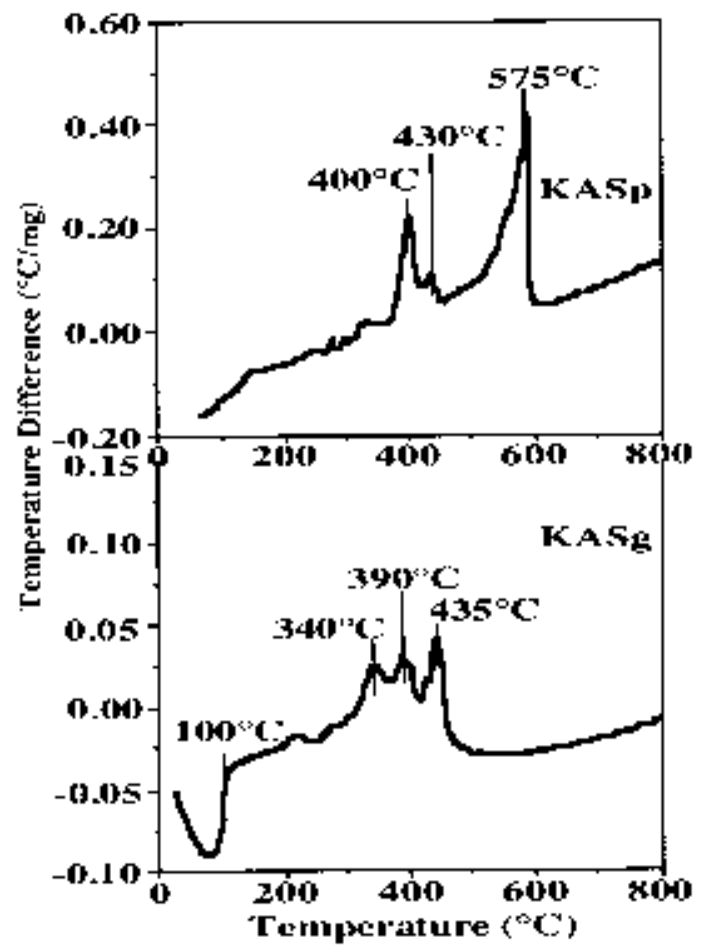

Fig. 3. DTA profiles of precursor and gel samples of KASp and KASg. Ramp rate was $2^{\circ} \mathrm{C} / \mathrm{min}$ to $300^{\circ} \mathrm{C}$, then $10^{\circ} \mathrm{C} / \mathrm{min}$ in synthetic air.

Because we observe the same exotherms in $\mathrm{N}_{2}$, neither exotherm is considered to result from ligand oxidation processes. Hence, we conclude that network formation is the cause of at least one exotherm. The other exotherm might be explained by pore collapse. The final low-temperature exotherm, observed at $575^{\circ} \mathrm{C}$, most likely results from the oxidation of char generated during ligand decomposition, which is promoted by oxidative crosslinking, as discussed in Section IV(4).

At higher temperatures, the DTAs of the $900^{\circ} \mathrm{C} \mathrm{KASp}$ and $900^{\circ} \mathrm{C}$ KASg samples show distinct exotherms at $1070^{\circ} \mathrm{C}$. These exotherms result from crystallization to phase-pure $\mathrm{KAlSiO}_{4}$ (kaliophilite), as confirmed by XRD (Figs. 4 and 5).

\section{(3) XRD}

The XRD patterns (Figs. 4 and 5) of KASp and KASg samples that have been heated to $900^{\circ} \mathrm{C}$ exhibit broad scattering peaks that are typical of amorphous materials. ${ }^{27}$ Samples heated to temperatures of $>900^{\circ} \mathrm{C}$ crystallize as expected, based on the DTA results. Crystallization appears complete in both samples on heating to $1200^{\circ} \mathrm{C}$, because no further changes appear in the $1400^{\circ} \mathrm{C}$ XRD spectra (not shown).

XRD does not distinguish between the ceramic products that have been prepared via the two routes. The XRD data, coupled with DTA and TGA data, suggest that the crystallization rates, atomic mixing, and diffusion are similar for both materials. However, DRIFTS and SEM studies suggest otherwise.

\section{(4) DRIFTS}

DRIFTS allows one to trace precursor decomposition processes and $\mathrm{KAlSiO}_{4}$ evolution at the atomic level, particularly to identify chemical moieties, atomic-level reorganization of $\mathrm{M}-\mathrm{O}$ bonds, and crystallization differences between KASp and $\mathrm{KASg}$, as a function of pyrolysis temperature. Three DRIFTS regions are discussed as follows.

(A) $v(O-H)$ Species: In the KASp spectra (Fig. 6), the $400^{\circ}-900^{\circ} \mathrm{C}$ samples exhibit a broad band, centered at $3300 \mathrm{~cm}^{-1}$. This $v(\mathrm{M}-\mathrm{O}-\mathrm{H})^{28}$ band is typical of $\mathrm{H}$-bonded $\mathrm{OH}$ resulting from physisorbed or chemisorbed $\mathrm{H}_{2} \mathrm{O}$. The $v(\mathrm{O}-\mathrm{H})$ intensities decrease as temperatures increase, as $\mathrm{H}_{2} \mathrm{O}$ is eliminated, and as SSAs decrease (see below). In contrast, $400^{\circ}-$ $900^{\circ} \mathrm{C} \mathrm{KASg}$ spectra (Fig. 7) exhibit a weak band centered at $3600 \mathrm{~cm}^{-1}$ that corresponds to isolated $v(\mathrm{O}-\mathrm{H})$ moieties. Similar to the KASp sample, the KASg $\nu(\mathrm{O}-\mathrm{H})$ intensities diminish as the temperature increases and the SSA decreases. The differences in $v(\mathrm{O}-\mathrm{H})$ peak positions and intensities are the first indication that the KASp and KASg samples are not identical, despite the identical processing conditions. Because the surface properties are anticipated to have a profound effect on ER behavior, the exact sources of these differences and the mostlikely processes for ligand decomposition need to be discussed.

In the following scheme, we consider a generic ethyleneoxy - Si bond and its thermolytic behavior. Given that the standard bond dissociation energies for $\mathrm{C}-\mathrm{H}, \mathrm{C}-\mathrm{O}$, and $\mathrm{Si}-\mathrm{O}$ bonds are, respectively, $\sim 410,360$, and $540 \mathrm{~kJ} / \mathrm{mol}(99,86$, and $128 \mathrm{kcal} / \mathrm{mol}^{29}$ ), the weakest bond is the $\mathrm{C}-\mathrm{O}$ bond. Therefore, on heating, $\mathrm{C}-\mathrm{O}$ bond scission is the most likely process to occur, generating $\mathrm{Si}-\mathrm{O}^{\circ}$ and $-\mathrm{CH}_{2} \mathrm{CH}_{2}$ radicals. Because these radicals are trapped in the polymer matrix and are unable to diffuse away from each other, abstraction processes can occur. For example, the $\mathrm{Si}^{-} \mathrm{O}^{\circ}$ radical could abstract $\mathrm{H}^{*}$ from an adjacent $\mathrm{CH}_{2}$ group. The end result is a $\beta$-elimination process, creating $\mathrm{Si}-\mathrm{OH}$ and vinyl groups as suggested by

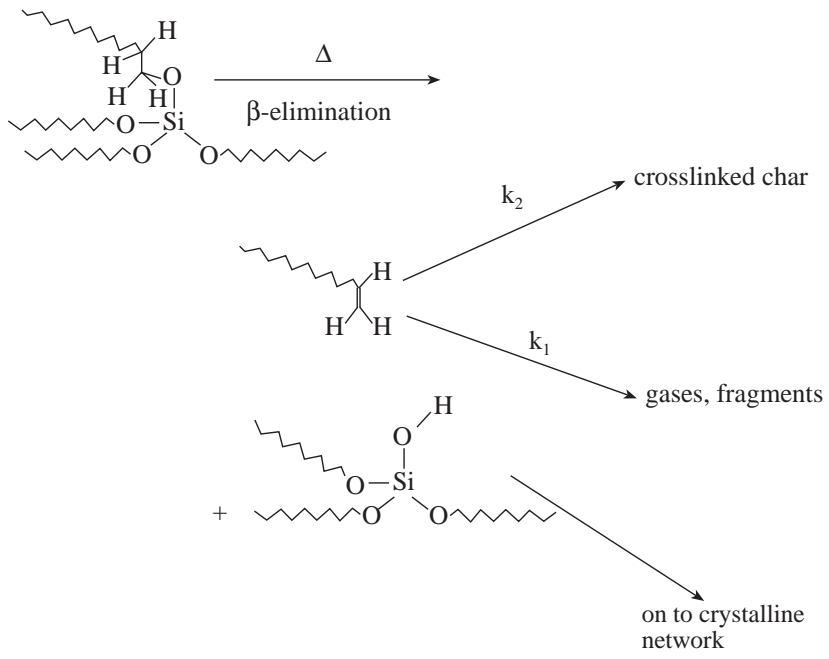

This explains the appearance of $\mathrm{Si}-\mathrm{OH}$ groups, especially at $400^{\circ} \mathrm{C}$. The vinyl coproduct can further react via one of two reaction pathways: tertiary bond scission, which results in volatilization of gaseous products, or polymerization with other vinyl groups or free radicals to form a crosslinked polymer network. The presence of trace amounts of $\mathrm{O}_{2}$ will actually promote polymerization-enhancing char formation, in part by generating radicals that polymerize vinyl groups and in part by generating free radicals that couple with themselves to enhance polymer network formation. ${ }^{5}$ The resulting polymer network will either fragment to gaseous species more slowly than the simple ethyleneoxy groups or char on further heating.

The mass loss in the $400^{\circ}-600^{\circ} \mathrm{C}$ range in the TGA is best explained in terms of char formation, followed by oxidation. If we further assume that the char still contains $\mathrm{C}-\mathrm{H}$ bonds, then oxidation will generate $\mathrm{CO}_{2}$ and $\mathrm{H}_{2} \mathrm{O}$. Given the high surface areas and fine porosities that are generated during the pyrolysis processes, it is likely that the resulting $\mathrm{CO}_{2}$ and $\mathrm{H}_{2} \mathrm{O}$ will only evolve slowly from the powders. Thus, the $\mathrm{H}_{2} \mathrm{O}$ that is formed has opportunities to physisorb and to chemisorb, which explains the continued presence of $\mathrm{OH}$ groups in the Fourier transform infrared (FTIR) spectra at temperatures up to $900^{\circ} \mathrm{C}$.

In KASp samples, heating leads to a decomposition of organics that generates $-\mathrm{OH}$ moieties, which, in turn, condense to form an extended oxide network. In contrast, KASg samples contain water-filled pores with pore surfaces consisting of $\mathrm{H}$-bonded $\mathrm{M}-\mathrm{O}-\mathrm{H}$ moieties $(\mathrm{M}=\mathrm{Si}, \mathrm{Al})$ that are formed during gel synthesis. The primary processes that are available to the gel samples on heating are the evolution of trapped $\mathrm{H}_{2} \mathrm{O}$ (80 wt $\%$ is lost in the $20^{\circ} \mathrm{C}$ range) and further condensation 


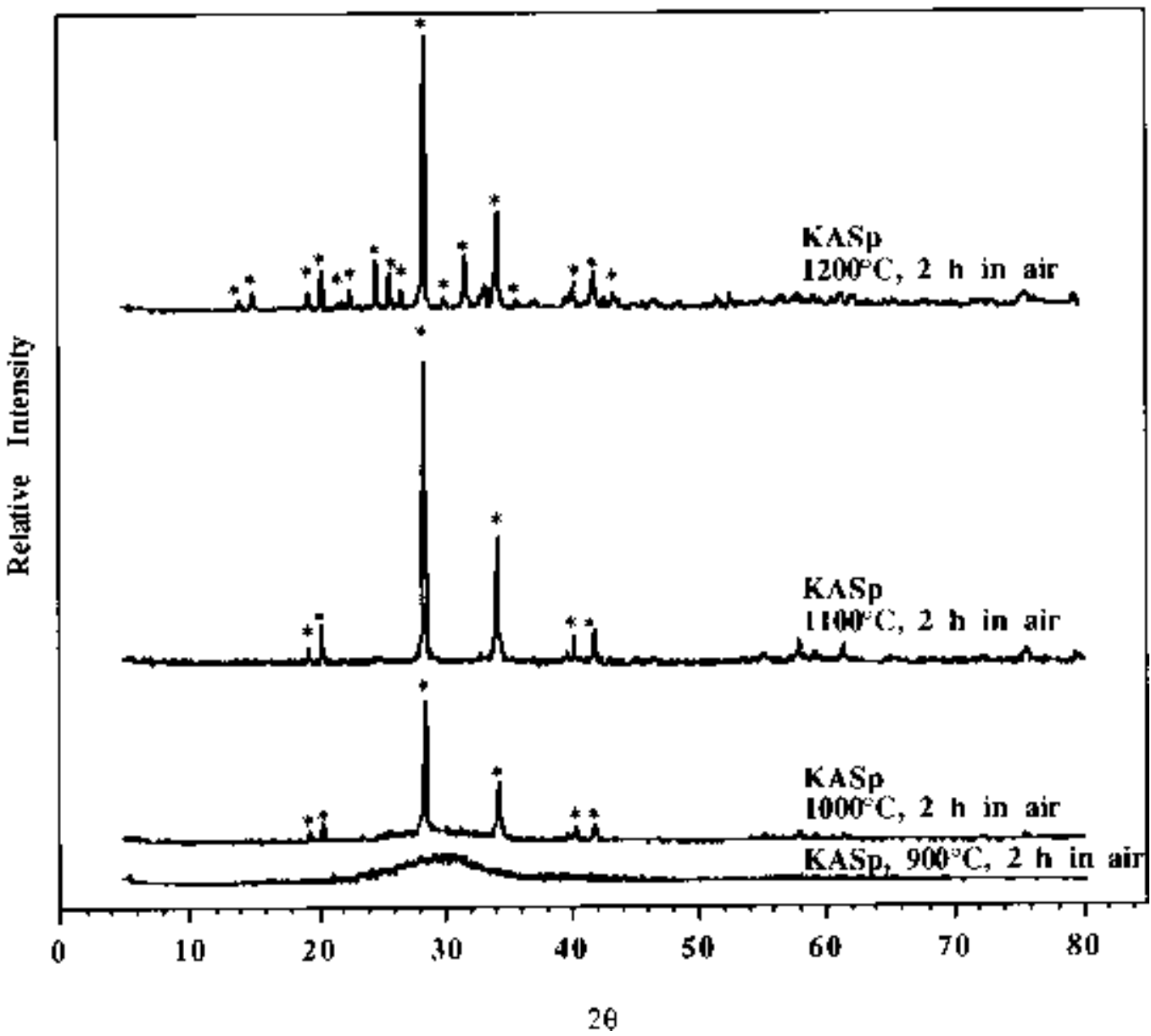

Fig. 4. XRD patterns of KASp samples; “*” corresponds to ICDD file 33-989, $\mathrm{KAlSiO}_{4}$.

with a concomitant loss of $\mathrm{H}_{2} \mathrm{O}$. Organic decomposition normally does not precede formation of $-\mathrm{OH}$ groups; thus, heating promotes direct formation of the extended oxide network, which implies that network formation should be faster; this is supported by DRIFTS spectra, showing only isolated $\mathrm{OH}$ moieties, $v(\mathrm{O}-\mathrm{H}) \approx 3600 \mathrm{~cm}^{-1}$.

Based on the differences in the $v(\mathrm{O}-\mathrm{H})$ regions for the KASg and KASp materials, we conclude that the rate of decomposition of organics and concomitant generation of $\mathrm{H}$-bonded surface $\mathrm{OH}$ is slower than the condensation of these $\mathrm{OH}$ to form $\mathrm{H}_{2} \mathrm{O}$ and an extended network. The rapid loss of $\mathrm{H}_{2} \mathrm{O}$ from KASg samples probably provides sufficient quantities of $\mathrm{H}_{2} \mathrm{O}$ in pores during evolution to solvate $\mathrm{K}^{+}$ions and transport them elsewhere in the pores. This is one possible source of the segregation that is observed in these samples, as discussed below.

(B) $\mathrm{CO}_{3}{ }^{2-}$ Species: In all the $400^{\circ}-700^{\circ} \mathrm{C} \mathrm{KASp}$ and KASg samples, bands appear in the region of $1350-1700 \mathrm{~cm}^{-1}$ that can be attributed to the $\mathrm{CO}_{3}{ }^{2-}$ species. ${ }^{28}$ These peaks match published spectra for $\mathrm{K}_{2} \mathrm{CO}_{3}{ }^{30}$ and spectra observed during decomposition of $\mathrm{K}_{2} \mathrm{Si}_{2}\left(\mathrm{OCH}_{2} \mathrm{CH}_{2} \mathrm{O}\right)_{5}$. ${ }^{3,31}$ The relative intensities decrease as the pyrolysis temperatures increase, as the carbonate decomposes/reacts. In KASp samples, all the carbonate species decompose before attaining a temperature of $900^{\circ} \mathrm{C}$. In the KASg spectra, the carbonate species are observed until a temperature of $1000^{\circ} \mathrm{C}^{3,31}$ is attained. No XRD patterns are observed for $\mathrm{K}_{2} \mathrm{CO}_{3}$, which is explained by the fact that it is amorphous or nanocrystalline or the concentration is too low and cannot be detected by XRD. ${ }^{3,5}$

$\mathrm{K}_{2} \mathrm{CO}_{3}$ (melting temperature of $891^{\circ} \mathrm{C}$ ) should still be present in samples that have been heated to $900^{\circ} \mathrm{C}$, unless it reacts as it melts. TGA studies show comparable weight losses $(<3 \mathrm{wt} \%$, ascribed to $\mathrm{CO}_{2}$ evolution) for KASp and KASg in the range of $800^{\circ}-950^{\circ} \mathrm{C}$, implying that reaction occurs as the carbonate melts. The disappearance of the carbonate peaks in $900^{\circ} \mathrm{C}$ KASp samples indicates complete reaction. The retention of carbonate peaks in $900^{\circ} \mathrm{C} \mathrm{KASg}$ samples suggests incomplete reaction and, therefore, a greater degree of segregation.

Higher-temperature processing, because of the increased rates of diffusion, can be expected to homogenize the segregated phases. This appears to occur in the KASg sample, as evidenced by changes in the $v(\mathrm{Si}-\mathrm{O})$ and $v(\mathrm{Al}-\mathrm{O})$ positions and intensities at higher temperatures.

(C) $v(M-O)$ Species: KASp and KASg spectra at $\geq 1000^{\circ} \mathrm{C}$ both show increasingly resolved and narrower peaks that are indicative of crystallization, as supported by the XRD and DTA studies. The high atomic order in crystalline materials reduces the total number of vibrational modes available; thus, specific vibrational modes-e.g., the tetrahedral $v(\mathrm{Si}-\mathrm{O})$ and $v(\mathrm{Al}-\mathrm{O})$ vibrations, at $1000 \mathrm{~cm}^{-1}$ and $700 \mathrm{~cm}^{-1}$, respectivelybecome much sharper with crystallization. ${ }^{3,31}$

In contrast, at temperatures of $<1000^{\circ} \mathrm{C}$, the intensities of the $v(\mathrm{Si}-\mathrm{O})$ and $v(\mathrm{Al}-\mathrm{O})$ peaks, at 1000 and $700 \mathrm{~cm}^{-1}$, respectively, in the KASg sample are much greater at all temperatures than those observed in the KASp spectra. The intensities suggest that the KASg samples are diphasic, because segregated regions of $\mathrm{SiO}_{2}$ and $\mathrm{Al}_{2} \mathrm{O}_{3}$ will exhibit $v(\mathrm{Si}-\mathrm{O})$ and $v(\mathrm{Al}-\mathrm{O})$ peaks that are representative of the individual materials. In contrast, atomically mixed materials will produce bands that are broad envelopes representative of numerous $v(\mathrm{Si}-\mathrm{O}-\mathrm{Al})$ species. The peak centered at $820 \mathrm{~cm}^{-1}$ is attributed to $\mathrm{Si}-\mathrm{O}-\mathrm{H}$ deformation vibrations ${ }^{32}$ and disappears before attaining a temperature of $500^{\circ} \mathrm{C}$, as the bridging $\mathrm{O}-\mathrm{H}$ species disappear.

DRIFTS studies suggest segregation at lower temperatures that is overcome on heating to $\geq 1000^{\circ} \mathrm{C}$. However, infrared 


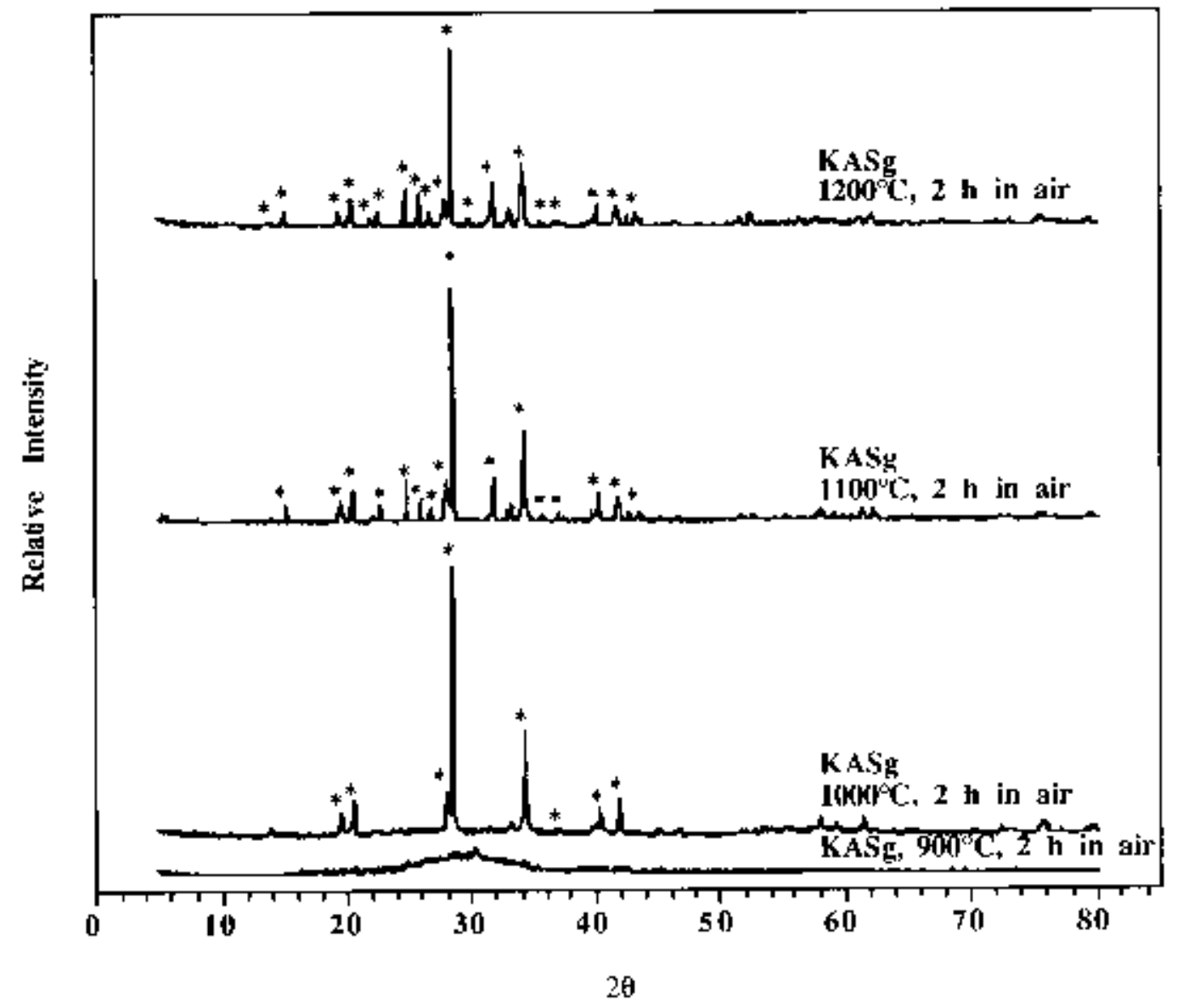

Fig. 5. XRD patterns of KASg samples; “*” corresponds to ICDD file 33-989, $\mathrm{KAlSiO}_{4}$.

spectroscopy studies are not infallible, as suggested by the SEM studies below.

\section{(5) Surface Area and Porosimetry}

Powder BET SSAs (Fig. 8) and pore-size distributions were determined to establish differences between KASp and KASg samples. As the pyrolysis temperatures increased, the surface areas decreased, as a result of coarsening, sintering, and coincident pore elimination. Surface area reduction will have a direct effect on ER behavior, which is surface area dependent.

Pore-size distributions that have been obtained from DFT (density functional theory) ${ }^{25}$ provide mean pore sizes of 4-5 nm for $400^{\circ}-700^{\circ} \mathrm{C} \mathrm{KASp}$. The $900^{\circ} \mathrm{C} \mathrm{KASp} \mathrm{samples} \mathrm{have} \mathrm{a} \mathrm{mean}$ pore size of $11 \mathrm{~nm}$. All KASp samples have a small number of macropores (up to $400 \mathrm{~nm}$ ). The increase in mean pore size (Fig. 9) with increases in the pyrolysis temperatures suggests the elimination of small pores with a concurrent merging of large pores.

In contrast, $400^{\circ}-700^{\circ} \mathrm{C} \mathrm{KASg}$ samples have mean pore sizes of 7-9 $\mathrm{nm}$, whereas the sample that has been pyrolyzed at $900^{\circ} \mathrm{C}$ has a mean pore size of $24 \mathrm{~nm}$. The KASg samples also have a small number of macropores (up to $400 \mathrm{~nm}$ ). The inherently larger mean pore sizes may be attributed to segregation and heterogeneity in the initial gel. The KASg samples also exhibit an increase in mean pore size at higher pyrolysis temperatures as diffusion eliminates smaller pores.

Coincident with the increasing pore size at increasing temperatures, cumulative pore volumes decrease (Fig. 10). For the KASp samples, the cumulative pore volume progressively decreases from $0.41 \mathrm{~cm}^{3} / \mathrm{g}\left(400^{\circ} \mathrm{C}\right)$ to $0.21 \mathrm{~cm}^{3} / \mathrm{g}\left(900^{\circ} \mathrm{C}\right)$. For the KASg samples, the cumulative pore volume decreases from $0.43 \mathrm{~cm}^{3} / \mathrm{g}\left(400^{\circ} \mathrm{C}\right)$ to $0.30 \mathrm{~cm}^{3} / \mathrm{g}\left(900^{\circ} \mathrm{C}\right)$. The differences in pore-volume reduction likely occurs because segregation in KASg samples (discussed in Section IV(4) above) hinders the elimination of pores that are trapped within segregated areas.
The porosimetry and SSA data, coupled with XRD data (above) and SEM findings (below), indicate that particle sintering and pore elimination result in a loss of SSA. ${ }^{33}$

\section{(6) SEM}

Crystallization and grain growth are evident in micrographs of $1000^{\circ} \mathrm{C} \mathrm{KASp}$ and KASg samples (Figs. 11(A) and (B), respectively). Figure 11(A) reveals the presence of uniform, sintered grains $(<1 \mu \mathrm{m})$ with residual porosity in the KASp sample. However, Fig. 11(B) shows that the KASg sample has much-larger, $5 \mu \mathrm{m}$ grains with very little porosity. The presence of a segregated glassy phase at the grain boundaries may be the reason why sintering and accelerated grain growth occur in KASg. SEM studies of crystalline KASp and KASg samples prove that sample segregation that has been detected in DRIFTS is not eliminated on heating to temperatures of $>1000^{\circ} \mathrm{C}$. These studies reveal significant crystallization and grain growth in the $900^{\circ}-1400^{\circ} \mathrm{C} \mathrm{KASp}$ and KASg samples, accompanied by segregation in the KASg samples up to $1400^{\circ} \mathrm{C}$.

\section{(7) ER Activity}

The use of OOPS-derived KAS powders in ER suspensions demonstrates a useful application of OOPS precursors. ${ }^{13}$ ER testing was conducted to determine the utility of the precursor and gel powders as ER materials and to quantify the ER behavior of both materials. The first step in the ER testing process was to establish a "moisture-free" system. This was accomplished by studying the effects of the moisture content of mineral oil on the ER behavior of NAS samples. ${ }^{24}$ These studies suggested that vacuum-dried mineral oil was sufficient for ER testing. Also, only samples that showed ER responses $\geq 5000$ $\mathrm{V} / \mathrm{mm}$ were deemed reliably dry and free of carbonaceous material.

Figure 12 records the ER behavior of KASp and KASg samples that have been processed at selected temperatures. For 


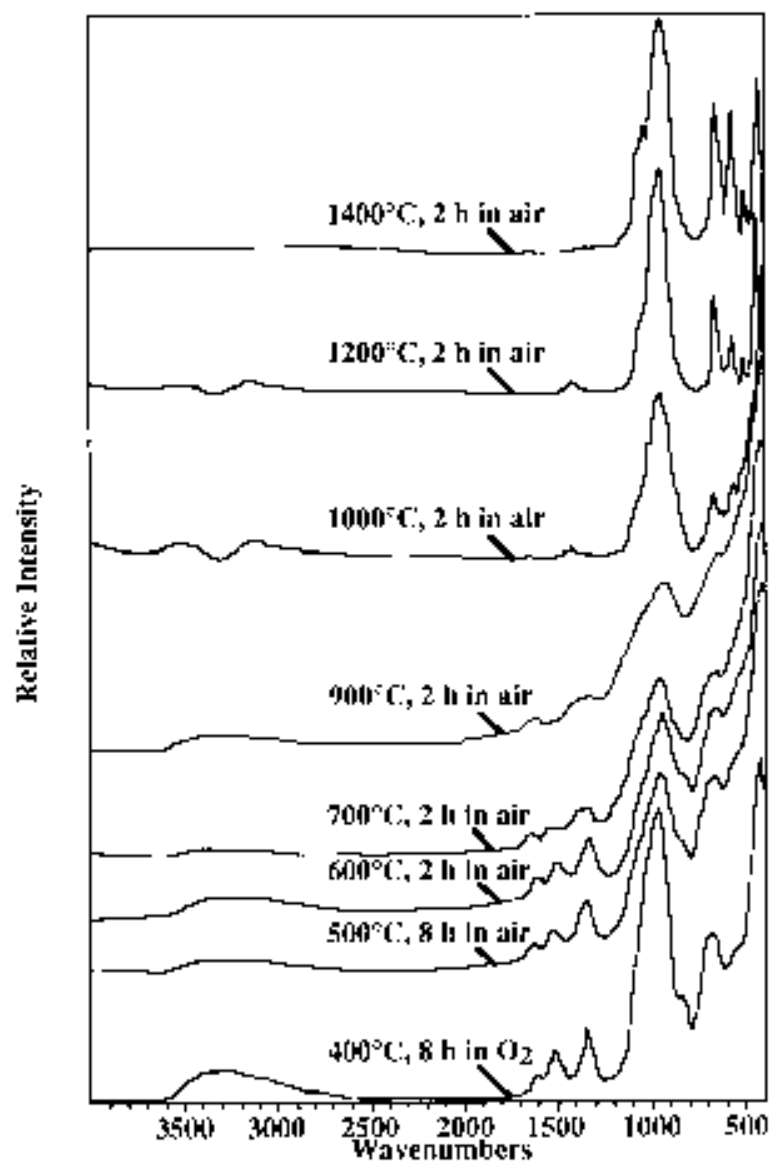

Fig. 6. DRIFT spectra of KASp samples.

the KASp powders, ER activity decreases as SSA decreases. From this, it is obvious that higher surface area, which affords increased opportunity for particle-electric-field interaction, provides better ER behavior. Such a correlation between SSA and ER behavior cannot be made for KASg powders, and this can be explained by their different surface chemistry and the inhomogeneity in the chemical composition offered by the solgel route.

To understand the ER activity of the KASg samples, it is first necessary to understand the concept of interfacial polarization. This phenomenon occurs when, in an electric field, an electric

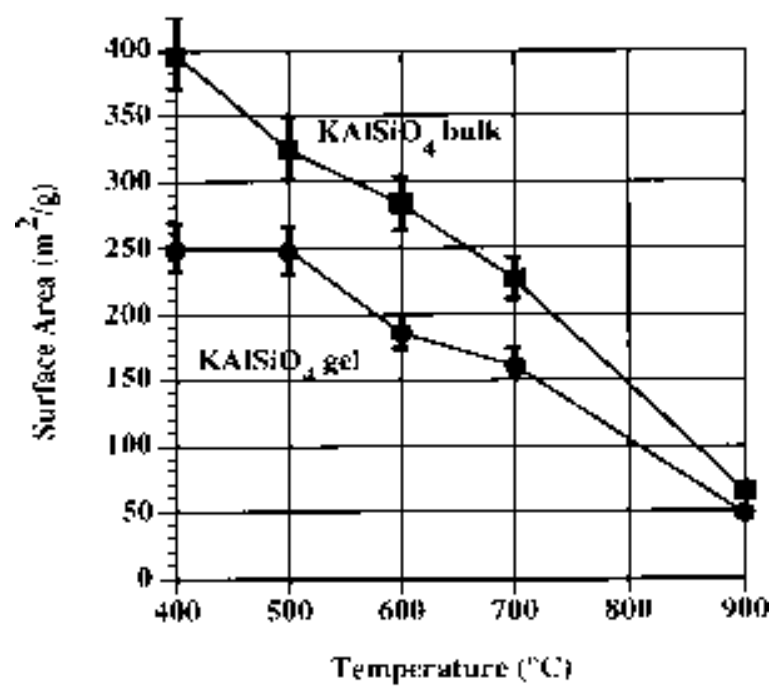

Fig. 8. BET surface areas of (ם) KASp and (-) KASg samples heated to selected temperatures in air/ $\mathrm{O}_{2}$ for $8 \mathrm{~h} / 2 \mathrm{~h}$.

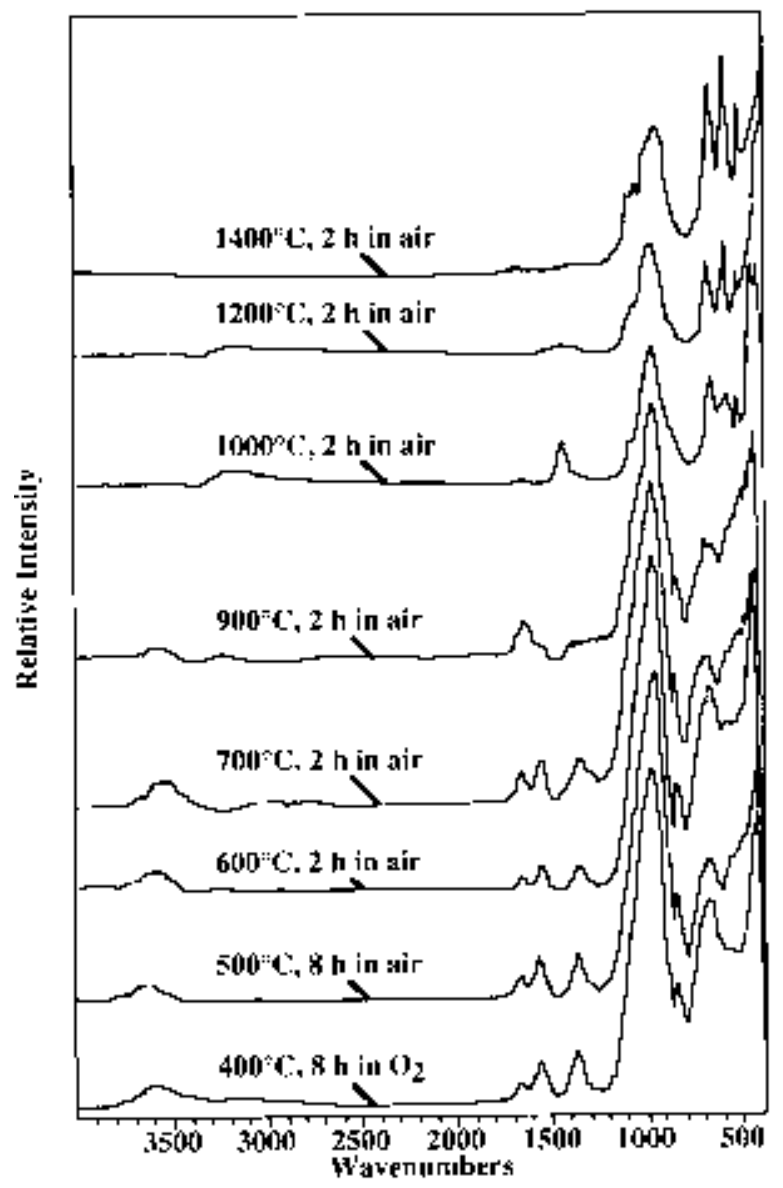

Fig. 7. DRIFT spectra of KASg samples.

conductor comes into contact with an insulator, and the charge carriers in the conductor migrate to the interface between the conductor (here, the surface $\mathrm{OHs}$ on KASg particles) and the insulator $^{34}$ (here, the mineral oil). The opposite electrical charges generate an electric attractive force ${ }^{34}$ between adjacent KASg particles. This force increases as the number of electrical charges increases, thereby increasing the ER effect. However, a threshold occurs when the surface charge carrier density is sufficient to produce an electric-field intensity that is higher

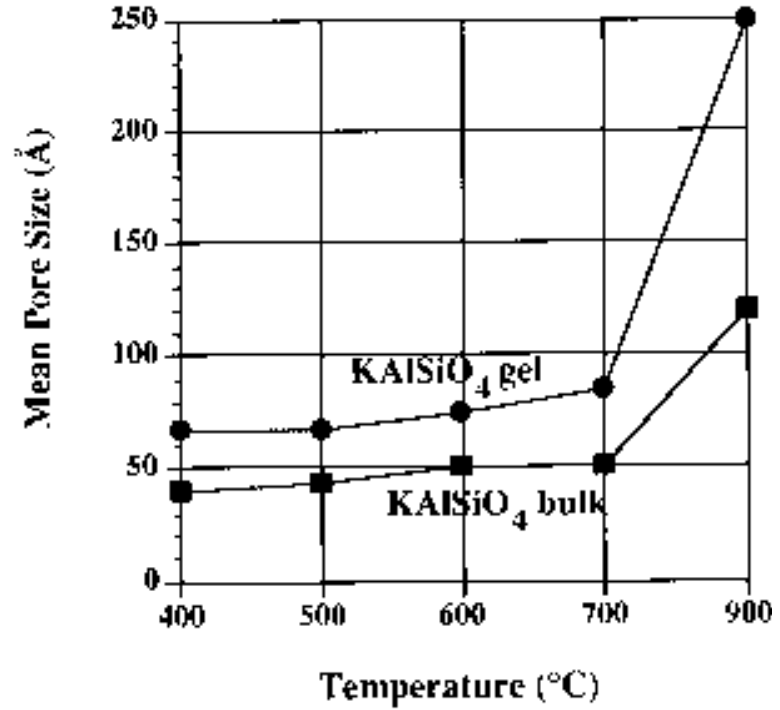

Fig. 9. Mean pore sizes (from DFT) for (ם) KASp and (@) KASg samples. 


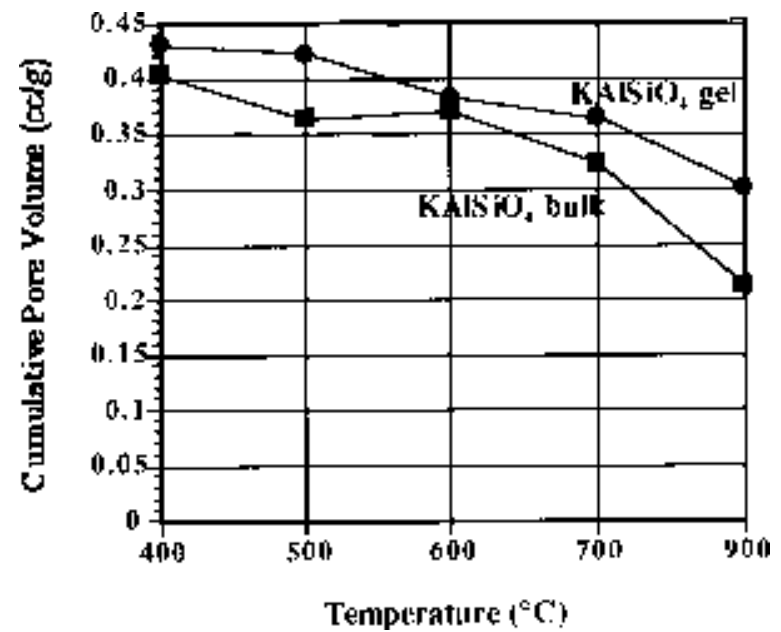

Fig. 10. Cumulative pore volumes (from DFT) for (ם) KASp and (O) KASg samples.

than the breakdown electric field of mineral oil. This results in the electric breakdown of the mineral oil, which, in turn, neutralizes the charge carriers and lowers the ER effect.

The lower ER behavior of the $400^{\circ}$ and $500^{\circ} \mathrm{C} \mathrm{KASg}$ samples can be explained as resulting from breakdown. Because the samples have high surface areas (Fig. 8), they also have a concentration of charge carriers, e.g., surface hydroxyls $(-\mathrm{OH}$ species), that is large enough to cause electric breakdown of the mineral oil, resulting in lower ER values. The $600^{\circ} \mathrm{C} \mathrm{KASg}$ powders exhibit the best ER behavior that is observed, possibly as a result of segregation of potassium ions (mobile charge carriers) to the surfaces of pores. Recall that, in drying, considerable amounts of $\mathrm{H}_{2} \mathrm{O}$ are generated in a short time, which might result in the transport of potassium ions to pore surfaces and segregation. Above this temperature, sintering (surfacearea loss) and diffusion of ions back into the bulk are likely to reduce the concentration of mobile surface charges, resulting in a loss of ER behavior. Both materials can be considered to be truly anhydrous $\left(<5\right.$ vol\% $\left.\mathrm{H}_{2} \mathrm{O}\right) .^{15}$ The KASg powders that have been pyrolyzed to $400^{\circ}, 500^{\circ}$, and $600^{\circ} \mathrm{C}$ and the KASp powders that have been pyrolyzed to $400^{\circ}$ or $500^{\circ} \mathrm{C}$ give ER behavior that is suitable $(>150 \mathrm{~Pa})$ for ER applications.

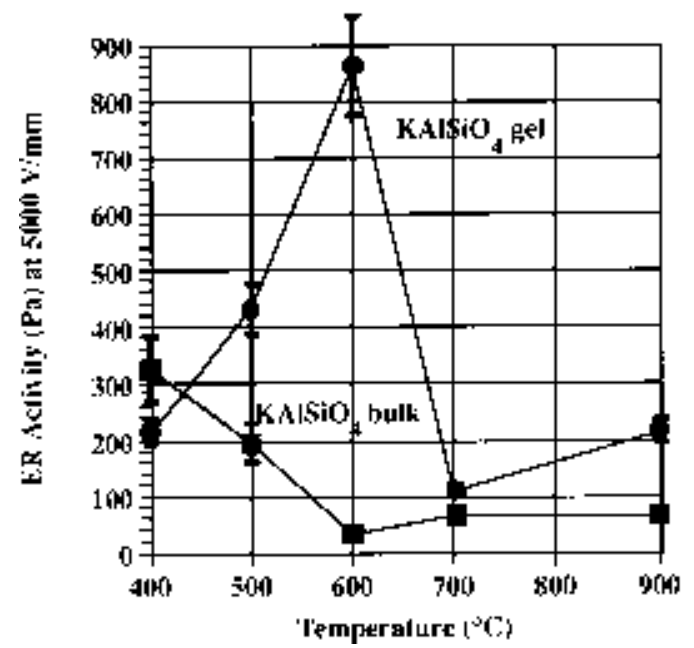

Fig. 12. ER activity of (ם) KASp and (-) KASg samples at $5000 \mathrm{~V} / \mathrm{mm}$

Although the purpose of this study was not to optimize the precursor and sol-gel processing routes, the precursor system provides more-uniform atomic mixing than the sol-gel system, which explains the differences in homogeneity and ER behavior in the KASp and KASg samples.

\section{Conclusions}

This work shows that OOPS-derived precursors are suitable for processing uniform, high-surface-area $\left(400 \mathrm{~m}^{2} / \mathrm{g}\right) \mathrm{KAlSiO}_{4}$ (KAS) composition bulk and gel powders with narrow poresize distributions (7-10 nm (70-100 A)). Although TGA, DTA, and XRD analyses show that the bulk and gel materials are identical, DRIFTS spectra and SEM analysis prove otherwise. They reveal that the KASp powders are homogeneous, whereas the KASg powders are heterogeneous and segregated. This segregation (observed by DRIFTS, SEM, and ER testing) results in slightly larger mean pore sizes for the gel-derived powders.

$\mathrm{KASg}$ and $\mathrm{KASp}$ materials both crystallize at $1070^{\circ} \mathrm{C}$; however, the KASg sample is segregated at this temperature, as
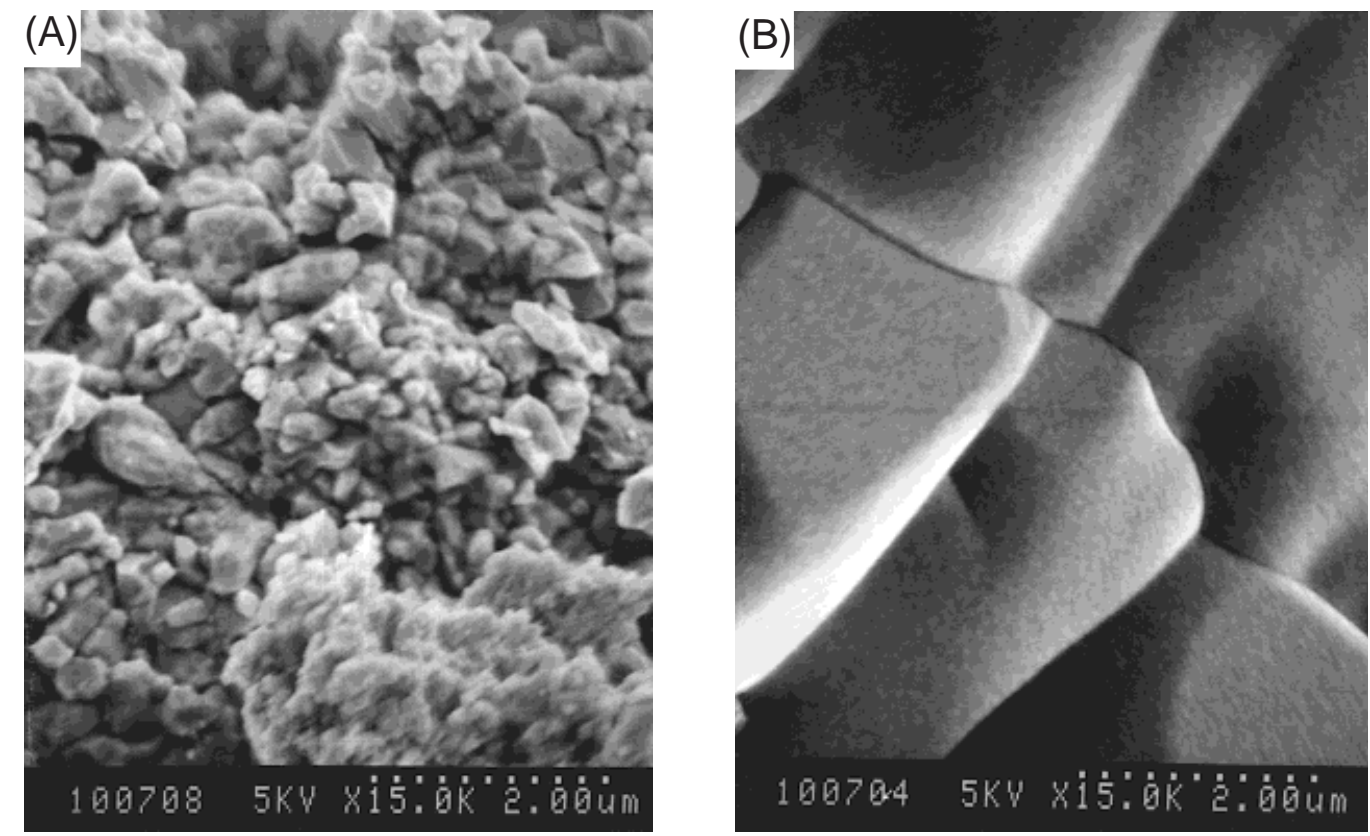

Fig. 11. SEM micrographs of (A) $1000^{\circ} \mathrm{C}$ KASp and (B) $1000^{\circ} \mathrm{C}$ KASg show sintered, uniform particles. 
shown by DRIFTS. KASp and KASg powders both are truly anhydrous and can be considered intrinsic ER materials. The KASg powders exhibit better ER behavior at $600^{\circ} \mathrm{C}$, possibly because of the presence of an optimal concentration of mobile charge carriers in the form of potassium ions that have segregated to the surface. The KASp powders exhibit ER behavior, possibly because of chemisorbed water, as observed in DRIFTS. The KASg powders that have been pyrolyzed to $400^{\circ}$, $500^{\circ}$, and $600^{\circ} \mathrm{C}$ and the KASp powders that have been pyrolyzed to $400^{\circ}$ or $500^{\circ} \mathrm{C}$ give ER behavior that is suitable $(>150 \mathrm{~Pa})$ for use in ER applications.

\section{References}

${ }^{1}$ C. J. Brinker and G. W. Scherer, Sol-Gel Science: The Physics and Chemistry of Sol-Gel Processing; pp. 454-60 and 737-47. Academic Press, Boston, MA, 1990.

${ }^{2}$ J. S. Reed, Principles of Ceramics Processing; p. 56. Wiley, New York, 1995.

${ }^{3}$ P. Kansal and R. M. Laine, "Pentacoordinate Silicon Complexes as Precursors to Silicate Glasses and Ceramics," J. Am. Ceram. Soc., 77, 875-82 (1994).

${ }^{4}$ J. Livage, M. Henry, and C. Sanchez, "Sol-Gel Chemistry of Transition Metal Oxides," Prog. Solid State Chem., 18, 259-341 (1988).

5 (a) P. Kansal and R. M. Laine, "Group II Tris(glycolato)silicates as Precursors to Silicate Glasses and Ceramics," J. Am. Ceram. Soc., 78, 529-38 (1995). (b) P. Kansal, "Novel Chemical Routes to Ceramics from Precursors," Ph.D. Thesis. University of Michigan, Dept. of Materials Science and Engineering, Ann Arbor, MI, 1996.

${ }^{6}$ (a) R. M. Laine, B. L. Mueller, and T. Hinklin, "Neutral and Mixed Neutral/ Anionic Polymetalloxanes," U.S. Pat. No. 5418928, May 23, 1995. (b) R. M Laine, D. R. Treadwell, B. L. Mueller, C. R. Bickmore, K. F. Waldner, and T. Hinklin, "Processable Aluminosilicate Alkoxide Precursors from Metal Oxides and Hydroxides. The Oxide One Pot Synthesis (OOPS) Process,' J. Chem. Mater, 8, 1592-93 (1996).

${ }^{7}$ T. R. Hinklin, S. S. Neo, K. W. Chew, and R. M. Laine, "Precursor Impregnation and Pyrolysis (PIP) Processing of Barium Aluminosilicate - Nicalon Composites"; pp. 117-28 in Ceramic Transactions, Vol. 74, Advances in Ceramic-Matrix Composites III. Edited by N. P. Bansal and J. P. Singh. American Ceramic Society, Westerville, OH, 1996.

${ }^{8}$ (a) C. R. Bickmore, K. F. Waldner, D. R. Treadwell, and R. M. Laine, "Flame Spray Pyrolysis of Magnesium Aluminate Double Alkoxide," J. Am. Ceram Soc., 79, 1419-23 (1996). (b) K. Waldner, R. M. Laine, C. Bickmore, S. Dumrongvaraporn, and S. Tayaniphan, "Synthesis, Processing and Pyrolytic Transformation of a Spinel Polymer Precursor Made from $\mathrm{MgO}$ and $\mathrm{Al}(\mathrm{OH})_{3}$," Chem. Mater., 8, 2850-57 (1996).

${ }^{9}$ R. Baranwal, A. Zika, B. L. Mueller, and R. M. Laine, "Preceramic Polymer Routes to Amorphous and Crystalline Aluminosilicate Powders for Electrorheological Applications. I."; pp. 157-69 in Progress in Electrorheology. Edited by K. Havelka and F. E. Filisko. Plenum Press, New York, 1995.

${ }^{10}$ K.Y. Blohowiak, D. R. Treadwell, B. L. Mueller, M. L. Hoppe, S. Jouppi, P. Kansal, K. W. Chew, C. L. S. Scotto, F. Babonneau, J. Kampf, and R. M. Laine, " $\mathrm{SiO}_{2}$ as a Starting Material for the Synthesis of Pentacoordinate Silicon Complexes, I," Chem. Mater., 6, 2177-92 (1994).

${ }^{11}$ R. M. Laine, B. L. Mueller, T. Hinklin, D. Treadwell, S. Dhumrongvaraporn, J. Rangsitphol, P. Punchalpetch, F. Babonneau, and J. A. Rock, "Neutral Alkoxyand Aryloxysilanes from $\mathrm{SiO}_{2}$ "; unpublished work.
${ }^{12}$ R. Narayanan and R. M. Laine, "Synthesis and Characterization of a Trimetallic Double-Alkoxide Precursor to Potassium Aluminosilicate"; in High Temperature Synthesis of Materials. Edited by D. Gowen, R. Malhotra, and M. Serio. American Chemical Society, Washington, DC, in press.

${ }^{13}$ (a) F. E. Filisko and L. H. Radzilowski, "Intrinsic Mechanism for Activity of Aluminosilicate Based Electrorheological Fluids," J. Rheol. (NY), 34, 539-52 (1990). (b) D. Gamota and F. E. Filisko, "High Frequency Dynamic Mechanical Study of an Alumino-Silicate Electrorheological Material," J. Rheol. (NY), 35, 1411-25 (1991)

${ }^{14}$ D. R. Gamota, A. W. Schubring, B. L. Mueller, and F. E. Filisko, "Amorphous Ceramics as the Particulate Phase in Electrorheological Materials Systems," J. Mater. Sci., 11, 144-55 (1996).

${ }^{15}$ T. C. Jordan and M. T. Shaw, "Electrorheology," IEEE Trans. Elec. Insul., 24, 849-77 (1989).

${ }^{16}$ W. M. Winslow, "Induced Fibration of Suspensions," J. Appl. Phys., 20, 1137-40 (1949).

${ }^{17}$ D. L. Klass and T. M. Martinek, "Electroviscous Fluids I. Rheological Properties," J. Appl. Phys., 38, 67-74 (1967).

${ }^{18}$ P. M. Adriani and A. P. Gast, "A Microscopic Model of Electrorheology," Phys. Fluids, 31. 2757-68 (1988)

${ }^{19}$ T. C. Jordan, "Electrorheological Fluids: An Investigation of Structural Mechanisms," Ph.D. Thesis. University of Connecticut, Storrs, CT, 1989.

${ }^{20}$ O. A. Chertkova, G. G. Petrzhik, and A. A. Trapeznikov, "The Influence of the Nature of Surfactant on the Electrorheological Effect of Nonaqueous Dispersions," Kolloidn. Zh., 44, 68-74 (1982).

${ }^{21}$ W. M. Winslow, "Method and Means for Translating Electrical Impulses into Mechanical Force," U.S. Pat. No. 2417 850, March 25, 1947.

22"Electrorheological (ER) Fluids," A Research Needs Assessment, DOE Final Report for Contract No. DE-AC02-91ER30172.

${ }^{23}$ D. R. Gamota, "Dynamic Mechanical Properties of an Electrorheological Material," Ph.D. Thesis. University of Michigan, Department of Materials Science and Engineering, Ann Arbor, MI, 1992.

${ }^{24} \mathrm{R}$. Baranwal and A. Zika; unpublished results.

${ }^{25}$ P. B. Balbuena and K. E. Gubbins, "Classification of Adsorption Behavior: Simple Fluids in Pores of Slit-Shaped Geometry," Fluid Phase Equilib., 76, 21 35 (1992).

${ }^{26}$ R. Nass, E. Tkalcec, and H. Ivankovic, "Single-Phase Mullite Gels Doped with Chromium,” J. Am. Ceram. Soc., 78, 3097-106 (1995).

${ }^{27}$ B. D. Cullity, Elements of X-Ray Diffraction; p. 29. Addison Wesley, Reading, MA, 1956

${ }^{28}$ R. P. Bauman, Absorption Spectroscopy; pp. 336-37. Wiley, New York, 1962.

${ }^{29}$ S. N. Ege, Organic Chemistry, 2nd Ed.; p. 69. D. C. Heath \& Co., Lexington, MA, 1989.

${ }^{30}$ Sadtler High Resolution Spectra of Inorganics and Related Compounds. Sadtler Research Laboratories, Philadelphia, PA, 1965.

${ }^{31}$ D. Lin-Vien, N. B. Colthup, W. G. Fateley, and J. G. Grasselli, The Handbook of Infrared and Raman Characteristic Frequencies of Organic Molecules pp. 119 and 258-59. Academic Press, Boston, MA, 1991.

${ }^{32} \mathrm{G}$. Socrates, Infrared Characteristic Group Frequencies; p. 128. Wiley, New York, 1980.

${ }^{33}$ W. D. Kingery, H. K. Bowen, and D. R. Uhlmann, Introduction to Ceramics; p. 475. Wiley-Interscience, New York, 1976.

${ }^{34}$ A. Kawai, K. Uchida, K. Kamiya, A. Gotoh, and F. Ikazaki, "Effect of Adsorbed Water Contained in Heat-Treated Silica Particles on Electrorheology," Adv. Powder Technol., 5, 129-41 (1994). 